\title{
Comparative Effect of Silymarin and D-Penicillamine on Lead Induced Hemotoxicity and Oxidative Stress in Rat
}

\author{
Seyedeh Missagh Jalali* ${ }^{1}$, Hossein Najafzadeh ${ }^{2}$, Seyedeh Maryam Mousavi ${ }^{3}$
}

Received: 02.11.2016

Accepted: 24.12.2016

\begin{abstract}
Background: This study was performed to investigate the adverse effects of acute lead intoxication on hemogram, erythrocyte osmotic fragility and oxidant/antioxidant status and the probable ameliorating effect of silymarin in comparison to d-penicillamine.

Methods: Forty-eight albino rats were divided in 8 groups and received the following treatments in a 10 day experiment in Shahid Chamran University of Ahvaz, southwest Iran in 2015. Group 1: Normal saline as control; Group 2: $25 \mathrm{mg} / \mathrm{kg}$ lead acetate, intraperitoneally (IP) for the last 5 days; Group 3: $100 \mathrm{mg} / \mathrm{kg}$ D-penicillamine, IP for the last 5 days; Group 4: $200 \mathrm{mg} / \mathrm{kg}$ silymarin, orally for 10 days; Group 5, 6, 7 and 8: In addition to lead, they received D-penicillamine, for the last 5 days, silymarin for 10 days, a combination of silymarin for 10 days and D-penicillamine for the last 5 days, and silymarin for the last 5 days, respectively.

Results: Lead exposure induced a significant microcytic anemia accompanied by a significant elevation in total leukocyte, lymphocyte and neutrophil counts. Erythrocyte superoxide dismutase (SOD) and glutathion peroxidase (Gpx) activities were significantly increased along with a significant elevation of malondialdehyde (MDA) concentration in lead treated rats. Activities of SOD and Gpx were significantly alleviated by silymarin administration for 10 days while both Dpenicillamine and silymarin could significantly reduce MDA concentration.

Conclusion: Acute lead exposure induced significant leukocytosis and anemia that was associated with increased activity of erythrocyte antioxidant enzymes and lipid peroxidation. Silymarin in contrast to D-penicillamine treatment was more effective in preventing lead-induced oxidative stress in erythrocytes.
\end{abstract}

Keywords: D-Penicillamine, Hemotoxicity, Lead Poisoning, Oxidative Stress, Silymarin.

\section{IJT 2017 (3): 11-18}

\section{INTRODUCTION}

Lead poisoning is the most widely studied occupational and environmental hazard to human and domestic animals [1]. This metal is widely employed in alloys, pigments, batteries and other industrial applications due to its characteristics including low melting point and high vapor pressure. This substantial lead consumption has resulted in environmental pollutions and various health hazards [2]. Blood serves as a major target for the toxic effects of inorganic lead besides being its route of transportation [3].

Hemoglobin synthesis is suppressed in $\mathrm{Pb}$ poisoning in consequence of the inhibition of enzymes that perform in this pathway. It also reduces the life span of circulating erythrocytes bydestruction of cell membranes [4].

Several mechanisms have been proposed to explain the $\mathrm{Pb}$-induced toxicity. One is induction of oxidative stress through the generation of reactive oxygen species and depletion of the cellular antioxidant pool [5].

D-penicillamine has been used for several decades in chelation treatment of lead toxicity [6]. D-penicillamine administration can reduce blood lead level through complexes, which it forms with this heavy metal and increasing its urinary excretion [7]. However, D-penicillamine is associated with a number of side effects, which reduce its clinical utilization as a metal chelator. Nephrotic syndrome and a range of autoimmune reactions are among the adverse effects of this drug observed in a significant proportion of treated patients [6].Herbal medicines derived from plant extracts are being increasingly utilized to treat a wide variety of clinical disease due to safe use, their antioxidative properties and their possible roles in intra and extracellular defense against oxidative stress [8]. Lead induced

1. Department of Clinical Sciences, Shahid Chamran University of Ahvaz, Ahvaz, Iran.

2. Department of Basic Sciences, Shahid Chamran University of Ahvaz, Ahvaz, Iran.

3. Doctor of Veterinary Medicine, Shahid Chamran University of Ahvaz, Ahvaz, Iran.

*Corresponding Author: E-mail: mi.jalali@ scu.ac.ir 
toxicities were alleviated by administration of various antioxidants including vitamin $\mathrm{C}, \mathrm{E}$, green tea, pectin and flaxseed oil [4].

Silymarin is a standardized mixture of antioxidant flavonolignans (silybin and silibinin) extracted from the medicinal plant Silybum marianum. It is a free radical scavenger and a membrane stabilizer that prevents lipoperoxidation induced cell damage [9] and was proved to have a protective effect against experimental hepatotoxicity [10]. Moreover, alternative beneficial effects of silymarin comprising cardioprotective, antidiabetic, antiinflammatory, and iron chelating were recently demonstrated [11-13].

To the best of our knowledge, there are no studies concerning the hemoprotective effect of silymarin against lead intoxication. Hence, the present study was carried out to investigate the adverse effect of acute lead intoxication on hemogram, erythrocyte osmotic fragility and erythrocyte oxidant/antioxidant status and the probable alleviating effect of silymarin in comparison to d-penicillamine against lead induced hemotoxicity.

\section{MATERIALS AND METHODS}

\section{Laboratory Animals}

This study was performed in the clinical pathology laboratory, faculty of veterinary medicine, Shahid Chamran University of Ahvaz, southwest Iran from October to December 2015. Forty eight albino female rats (Wistar strain) weighing 180-200 g were housed in groups of 6, in plastic cages, in an air-conditioned room maintained at a temperature of $24 \pm 2{ }^{\circ} \mathrm{C}$ and a relative humidity of $55 \pm 5 \%$, with a $12 \mathrm{~h}$ light/dark illumination cycle. They were fed a commercial laboratory pelleted diet and tap water ad libitum.

All procedures were done in accordance with ethical guidelines for care and use of laboratory animals. The study was approved by the Experimental Animals Committee of Shahid Chamran University of Ahvaz, Iran.

\section{Experimental Design}

Animals were equally and randomly divided into 8 groups. All groups were subjected to a 10day experiment as follows:

Group 1 (negative control): $0.5 \mathrm{ml}$ saline $(0.9 \% \mathrm{NaCl})$, intraperitoneally (IP) for 10 days.

Group 2: $25 \mathrm{mg} / \mathrm{kg}$ lead acetate (Merck, Germany), IP for the last 5 days [14].
Group $\quad 3: 100 \quad \mathrm{mg} / \mathrm{kg} \quad$ D-penicillamine(Sigma Chemical Co., USA),IP for the last 5 days [15].

Group 4: $200 \mathrm{mg} / \mathrm{kg}$ silymarin (Sigma Alderich, USA), orally by gavage for 10 days [16].

Group 5: $25 \mathrm{mg} / \mathrm{kg}$ lead acetate and $100 \mathrm{mg} / \mathrm{kg}$ Dpenicillamine, IP for the last 5 days.

Group 6: $200 \mathrm{mg} / \mathrm{kg}$ silymarin orally by gavage for 10 days and $25 \mathrm{mg} / \mathrm{kg}$ lead acetate, IP for the last 5 days.

Group 7: $200 \mathrm{mg} / \mathrm{kg}$ silymarin orally by gavage for 10 days, $25 \mathrm{mg} / \mathrm{kg}$ lead acetate and $100 \mathrm{mg} / \mathrm{kg}$ D-penicillamine for the last 5 days.

Group 8: $200 \mathrm{mg} / \mathrm{kg}$ silymarin orally by gavage and $25 \mathrm{mg} / \mathrm{kg}$ lead acetate, IP for the last 5 days.

\section{Blood Collection and Preparation of Hemolysate}

At the end of experimental period, rats were anesthetized with chloroform (Merck, Germany) and blood samples were collected via cardiac puncture into EDTA containing tubes. The blood samples were used for hematologic and osmotic fragility assessment and the remaining were transformed to hemolysate in order to analyze oxidant/antioxidant status. To prepare hemolysate, erythrocytes were washed 4 times with $0.9 \% \mathrm{NaCl}$ solution and mixed with cold redistilled water. The lysate was subsequently diluted with 0.01 $\mathrm{mol} / \mathrm{l}$ phosphate buffer $\mathrm{pH} 7.0$, so that a final dilution factor of 100 would be obtained. The prepared hemolysates were then stored at $-70{ }^{\circ} \mathrm{C}$ until performing further analysis.

\section{Hematological Assessment}

Complete blood counts including, total erythrocyte count (RBC), hematocrite value (HCT), hemoglobin concentration $(\mathrm{Hb})$, mean corpuscular volume (MCV), mean corpuscular hemoglobin (MCH), mean corpuscular hemoglobin concentration (MCHC), and total white blood cells (WBC) were determined by the BC-2800Vet hematology analyzer (Mindray, China). Differential leukocyte counts were also estimated manually as described by Meyer and Harvey (2004) [17].

\section{Saline Osmotic Fragility (of) Test}

Osmotic fragility test was performed on erythrocytes from all blood samples. A $10 \%$ phosphate buffered $\mathrm{NaCl}$ stock solution was prepared [18]. A $1 \%$ salt working solution was then serially diluted with distilled water to make a series of 16 tubes of $0.85,0.80,0.75,0.70,0.65$, $0.60,0.55,0.50,0.45,0.40,0.35,0.30,0.25,0.20$, 
0.10 , and $0 \%$ salt solutions. Twenty microliters of whole blood was added to each tube and mixed. The tubes were incubated at $25^{\circ} \mathrm{C}$ for $30 \mathrm{~min}$, and then centrifuged at $450 \mathrm{~g}$ for $10 \mathrm{~min}$. Optical density (OD) of each supernatant was read at 540 $\mathrm{nm}$ against distilled water using a spectrophotometer (Optima SP 3000 plus, Tokyo, Japan). Percentage hemolysis was calculated at each concentration of $\mathrm{NaCl}$ considering the 16th tube as $100 \%$ hemolysis. A graph of hemolysis percent against salt concentration was plotted. The concentration of $\mathrm{NaCl}$ causing $50 \%$ hemolysis was expressed as median corpuscular fragility (MCF).

\section{Determination of Lipid Peroxidation and Antioxidant Status}

The lipid peroxidation end product, malondialdehyde (MDA), was measured as thiobarbituric acid reactive substance in hemolysates [19].

The activities of antioxidant enzymes including superoxide dismutase (SOD) and glutathione peroxidase (GPX) were assayed using commercial assay kits according to the manufacturer's instructions (Randox Laboratories Ltd. G.B.).

\section{Statistical Analysis}

Analysis of variance (ANOVA) and Tukey's Post Hoc tests were employed to compare the data between groups using SPSS software (SPSS Inc., Chicago, IL, USA). All values were expressed as mean \pm standard error (SE) and $P<0.05$ was considered as statistically significant.

\section{RESULTS \\ Hematological Assessment}

Total leukocyte and lymphocyte counts were elevated in all lead exposed rats so that they were significantly different in groups 2 (Lead), 5 $($ Lead + pen $)$ and 8 (Lead + Sil. 5d) when compared to control group $(P<0.05)$ (Table 1$)$. A significant rise was also observed in neutrophil count, consistent with total leukocytes, in all lead treated groups regardless of the type of treatment $(P<0.05)$.

Mean erythrocyte count, hemoglobin concentration and hematocrit were significantly decreased in groups 2, 5, 6, 7 and 8 (all lead exposed groups) in comparison to control group $(P<0.05)$ (Table 2). In addition, a significant decline was noticed in MCV values of all groups with lead exposure $(P<0.05)$. Mean $\mathrm{MCH}$ values were also reduced in the mentioned groups, although insignificantly $(P \geq 0.05)$. There were no significant differences in MCHC, RDW and platelet count between groups.

\section{Saline Osmotic Fragility (of) Analysis}

There were no significant changes in percentage hemolysis in various salt concentrations between different groups (Figure 1). Median corpuscular fragility (MCF) was also unaffected by different treatments $(P \geq 0.05)$ (Table 2).

\section{Oxidant/Antioxidant Assessment}

Erythrocyte SOD activity was significantly increased in group 2 (Lead), 5 (Lead + pen), 7 $($ Lead + Pen + Syl. 10d $)$ and 8 (Lead + Sil. 5d) $(P<0.05)$ accompanied by a significant rise in $\mathrm{Gpx}$ activity of groups 2 and $5(P<0.05)$ (Table 3$)$. Concentration of MDA was significantly elevated due to lead exposure in rats of group 2 while this effect was alleviated by D-penicillamine or silymarin treatments in groups 5, 6 (Lead + Sil. 10d), 7 and $8(P<0.05)$ (Table 3$)$.

Table 1. Leukogram and platelet assessment results as mean \pm SE in different groups.

\begin{tabular}{|c|c|c|c|c|c|c|c|c|}
\hline & Cont & Lead & pen & Sil (10d) & $\begin{array}{l}\text { Lead + } \\
\text { pen }\end{array}$ & $\begin{array}{l}\text { Lead + } \\
\text { Sil (10d) }\end{array}$ & $\begin{array}{l}\text { Lead + Pen } \\
+ \text { Sil (10d) }\end{array}$ & $\begin{array}{l}\text { Lead + } \\
\text { Sil (5d) }\end{array}$ \\
\hline $\begin{array}{l}\text { WBC } \\
\left(\times 10^{3} / \mu \mathrm{l}\right)\end{array}$ & $\begin{array}{l}5.96 \pm \\
0.95\end{array}$ & & & & $\begin{array}{l}19.84 \pm \\
5.7 *\end{array}$ & $\begin{array}{l}13.04 \pm \\
4.12\end{array}$ & $\begin{array}{l}14.44 \pm \\
4.08\end{array}$ & \\
\hline $\begin{array}{l}\operatorname{Lym} \\
\left(\times 10^{3} / \mu 1\right)\end{array}$ & $4.1 \pm 0.7$ & $8.33 \pm 0.9 *$ & $\begin{array}{l}3.65 \pm \\
0.9\end{array}$ & $\begin{array}{l}4.76 \pm \\
1.27\end{array}$ & $\begin{array}{l}9.24 \pm \\
2.22 *\end{array}$ & $\begin{array}{l}5.28 \pm \\
1.32\end{array}$ & $6.82 \pm 1.93$ & \\
\hline $\begin{array}{l}\text { Mon } \\
\left(\times 10^{3} / \mu 1\right)\end{array}$ & $\begin{array}{l}0.2 \pm \\
0.03\end{array}$ & $0.35 \pm 0.03$ & $\begin{array}{l}0.21 \pm \\
0.04\end{array}$ & $\begin{array}{l}0.5 \pm \\
0.36\end{array}$ & $\begin{array}{l}0.32 \pm \\
0.06\end{array}$ & $\begin{array}{l}0.2 \\
\pm 0.07\end{array}$ & $0.54 \pm 0.23$ & $\begin{array}{l}0.32 \pm \\
0.08\end{array}$ \\
\hline $\begin{array}{l}\text { Neut } \\
\left(\times 10^{3} / \mu \mathrm{l}\right)\end{array}$ & $\begin{array}{l}1.66 \pm \\
0.23\end{array}$ & $9.6 \pm 1.13^{*}$ & $\begin{array}{l}1.83 \pm \\
0.28\end{array}$ & $\begin{array}{l}2.61 \pm \\
1.05\end{array}$ & $\begin{array}{l}8.22 \pm \\
1.73 *\end{array}$ & $\begin{array}{l}7.85 \pm \\
2.8 *\end{array}$ & $\begin{array}{l}7.08 \pm \\
2.04 *\end{array}$ & $\begin{array}{l}8.36 \pm \\
1.14 *\end{array}$ \\
\hline $\begin{array}{l}\text { Plt } \\
\left(\times 10^{3} / \mu l\right)\end{array}$ & $\begin{array}{l}452.16 \pm \\
29.09\end{array}$ & $\begin{array}{l}430.28 \pm \\
52.92\end{array}$ & $\begin{array}{l}489.0 \pm \\
39.83\end{array}$ & $\begin{array}{l}476.83 \pm \\
19.57\end{array}$ & $\begin{array}{l}368.33 \pm \\
78.51\end{array}$ & $\begin{array}{l}356.16 \pm \\
57.81\end{array}$ & $\begin{array}{l}547.66 \pm \\
20.81\end{array}$ & $\begin{array}{l}362.25 \\
\pm 83.97 \\
\end{array}$ \\
\hline
\end{tabular}

$*$ in each row indicates significant difference compared to control group. 
Table 2. Erythrocyte assessment results as mean \pm SE in different groups.

\begin{tabular}{|c|c|c|c|c|c|c|c|c|}
\hline & Cont & Lead & pen & Sil (10d) & $\begin{array}{l}\text { Lead + } \\
\text { pen }\end{array}$ & $\begin{array}{l}\text { Lead + Sil } \\
\text { (10d) }\end{array}$ & $\begin{array}{l}\text { Lead + Pen } \\
+ \text { Sil (10d) }\end{array}$ & $\begin{array}{l}\text { Lead + Sil } \\
(5 d)\end{array}$ \\
\hline $\begin{array}{l}\mathrm{RBC} \\
\left(\times 10^{6} / \mu \mathrm{l}\right)\end{array}$ & $\begin{array}{l}7.51 \pm \\
0.36\end{array}$ & $\begin{array}{l}5.95 \pm \\
0.16 *\end{array}$ & $7.3 \pm 0.25$ & $\begin{array}{l}7.54 \pm \\
0.34\end{array}$ & $\begin{array}{l}6.39 \pm \\
0.74 *\end{array}$ & $\begin{array}{l}6.8 \pm \\
0.27 *\end{array}$ & $\begin{array}{l}5.76 \pm \\
0.23 *\end{array}$ & $\begin{array}{l}6.02 \pm \\
0.24 *\end{array}$ \\
\hline $\mathrm{Hb}(\mathrm{g} / \mathrm{dl})$ & $14 \pm 0.68$ & $\begin{array}{l}10.45 \pm \\
0.3^{*}\end{array}$ & $\begin{array}{l}12.83 \pm \\
0.62\end{array}$ & $\begin{array}{l}13.65 \pm \\
0.58\end{array}$ & $\begin{array}{l}10.53 \pm \\
1.46^{*}\end{array}$ & $\begin{array}{l}11.23 \pm \\
0.66 *\end{array}$ & $\begin{array}{l}10.2 \pm \\
0.53 *\end{array}$ & $\begin{array}{l}10.03 \pm \\
0.38 *\end{array}$ \\
\hline HCT (\%) & $\begin{array}{l}49.58 \pm \\
2.36\end{array}$ & $\begin{array}{l}35.5 \pm \\
0.48 *\end{array}$ & $\begin{array}{l}46.48 \pm \\
1.93\end{array}$ & $\begin{array}{l}49.53 \pm \\
2.18\end{array}$ & $\begin{array}{l}37.45 \pm \\
5.11 *\end{array}$ & $\begin{array}{l}40.13 \pm \\
2.19 *\end{array}$ & $\begin{array}{l}35.95 \pm \\
1.83 *\end{array}$ & $\begin{array}{l}35.88 \pm \\
1.28 *\end{array}$ \\
\hline $\operatorname{MCV}$ (fl) & $\begin{array}{l}66.13 \pm \\
1.62\end{array}$ & $\begin{array}{l}60.58 \pm \\
0.65 *\end{array}$ & $\begin{array}{l}63.63 \pm \\
0.74\end{array}$ & $\begin{array}{l}65.8 \pm \\
0.81\end{array}$ & $\begin{array}{l}58.11 \pm \\
0.95^{*}\end{array}$ & $\begin{array}{l}60.97 \pm \\
0.59 *\end{array}$ & $\begin{array}{l}60.38 \pm \\
0.86^{*}\end{array}$ & $\begin{array}{l}59.7 \pm \\
0.43^{*}\end{array}$ \\
\hline $\mathrm{MCH}(\mathrm{pg})$ & $\begin{array}{l}18.58 \pm \\
0.39\end{array}$ & $\begin{array}{l}\text { 17.11 } \pm \\
0.18 *\end{array}$ & $\begin{array}{l}17.46 \pm \\
0.26\end{array}$ & $\begin{array}{l}18.08 \pm \\
0.14\end{array}$ & $\begin{array}{l}16.28 \pm \\
0.37 *\end{array}$ & $\begin{array}{l}16.93 \pm \\
0.25^{*}\end{array}$ & $\begin{array}{l}17.03 \pm \\
0.18 *\end{array}$ & $\begin{array}{l}16.61 \pm \\
0.06 *\end{array}$ \\
\hline $\begin{array}{l}\text { MCHC } \\
(\%)\end{array}$ & $\begin{array}{l}28.18 \pm \\
0.19\end{array}$ & $\begin{array}{l}28.15 \pm \\
0.17\end{array}$ & $\begin{array}{l}27.51 \pm \\
0.24\end{array}$ & $\begin{array}{l}27.5 \pm \\
0.19\end{array}$ & $\begin{array}{l}28.08 \pm \\
0.47\end{array}$ & $\begin{array}{l}27.31 \pm \\
0.08\end{array}$ & $\begin{array}{l}28.56 \pm \\
0.15\end{array}$ & $\begin{array}{l}27.90 \pm \\
0.17\end{array}$ \\
\hline RDW & $\begin{array}{l}12.68 \pm \\
0.41\end{array}$ & $12.9 \pm 0.18$ & $\begin{array}{l}11.33 \pm \\
0.34\end{array}$ & $\begin{array}{l}11.4 \pm \\
0.33\end{array}$ & $\begin{array}{l}12.43 \pm \\
0.37\end{array}$ & $\begin{array}{l}12.21 \pm \\
0.27\end{array}$ & $12.3 \pm 0.27$ & $\begin{array}{l}11.58 \pm \\
0.27\end{array}$ \\
\hline $\operatorname{MCF}(\%)$ & $\begin{array}{l}0.505 \pm \\
0.005\end{array}$ & $\begin{array}{l}0.504 \pm \\
0.015\end{array}$ & $\begin{array}{l}0.523 \pm \\
0.009\end{array}$ & $\begin{array}{l}0.529 \pm \\
0.004\end{array}$ & $\begin{array}{l}0.516 \pm \\
0.011\end{array}$ & $\begin{array}{l}0.531 \pm \\
0.007\end{array}$ & $\begin{array}{l}0.491 \pm \\
0.014\end{array}$ & $\begin{array}{l}0.516 \pm \\
0.010\end{array}$ \\
\hline
\end{tabular}

* in each row indicates significant difference compared to control group.

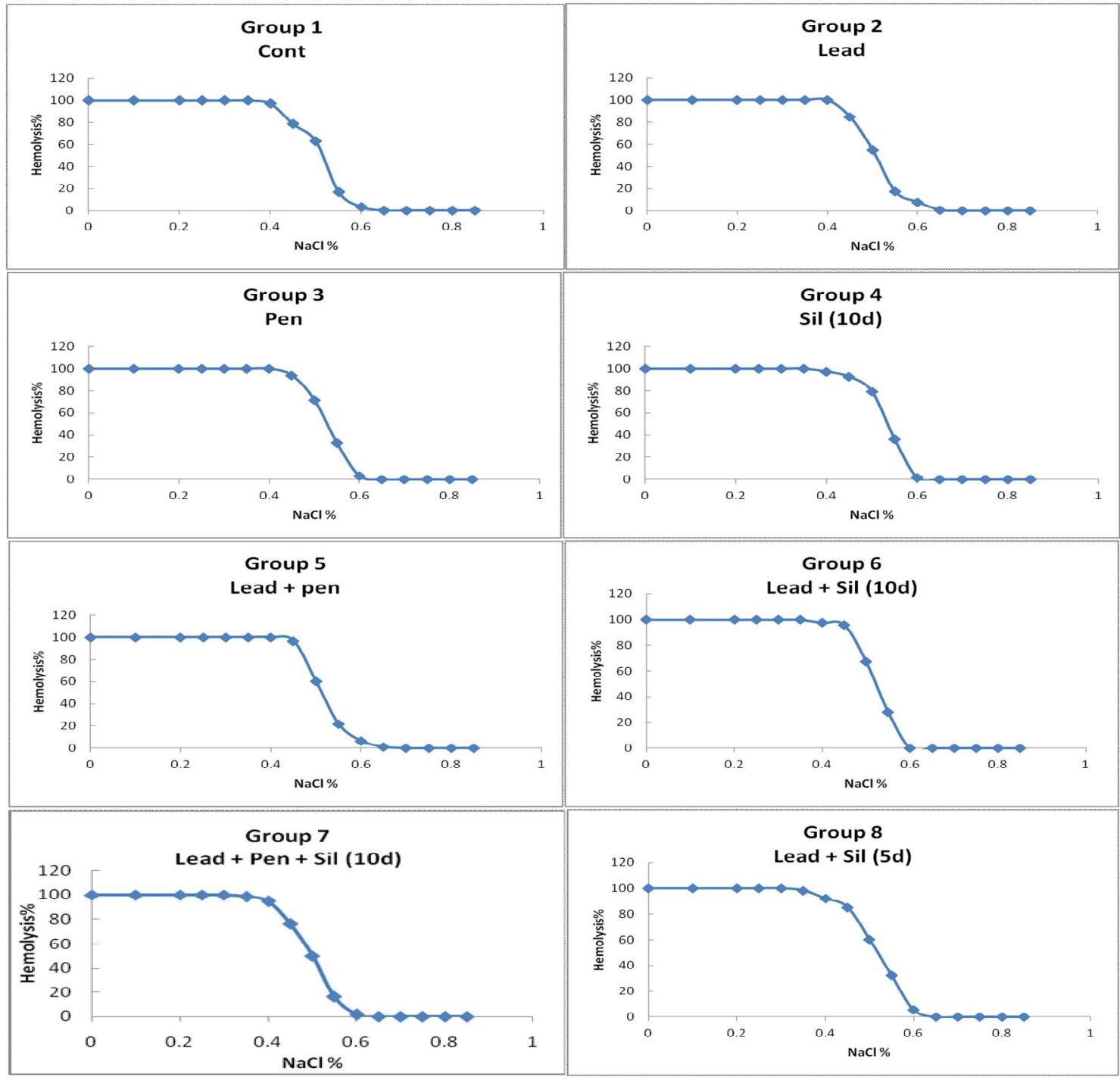

Figure 1. Mean erythrocyte Osmotic Fragility (OF) plots in different groups. 
Table 3. Oxidant/antioxidant assessment results as mean \pm SE in different groups.

\begin{tabular}{ccccccccc}
\hline & Cont & Lead & pen & Sil (10d) & $\begin{array}{c}\text { Lead }+ \\
\text { pen }\end{array}$ & $\begin{array}{c}\text { Lead }+ \text { Sil } \\
(10 \mathrm{~d})\end{array}$ & $\begin{array}{c}\text { Lead }+ \text { Pen } \\
+ \text { Sil }(10 \mathrm{~d})\end{array}$ & $\begin{array}{c}\text { Lead }+ \\
\text { Sil }(5 \mathrm{~d})\end{array}$ \\
\hline SOD & $2884.0 \pm$ & $\mathbf{3 8 0 5 . 9} \pm$ & $3143.6 \pm$ & $2971.4 \pm$ & $\mathbf{4 0 2 1 . 9} \pm$ & $3227.0 \pm$ & $\mathbf{4 3 5 9 . 1} \pm$ & $\mathbf{3 9 9 1 . 5} \pm$ \\
$(\mathrm{U} / \mathrm{gHb})$ & $145.70 \mathrm{a}^{*}$ & $\mathbf{1 0 6 . 2 5} \mathrm{b}$ & $141.29 \mathrm{ab}$ & $145.75 \mathrm{a}$ & $\mathbf{3 9 3 . 5 9} \mathrm{b}$ & $169.22 \mathrm{ab}$ & $\mathbf{3 7 3 . 3 5} \mathrm{b}$ & $\mathbf{1 4 9 . 9 9} \mathrm{b}$ \\
$\mathrm{Gpx}$ & $144.45 \pm$ & $\mathbf{2 5 1 . 8 8} \pm$ & $117.92 \pm$ & $81.36 \pm 14.32$ & $\mathbf{2 0 1 . 3 5} \pm$ & $83.36 \pm 15.57$ & $80.77 \pm$ & $177.61 \pm$ \\
$(\mathrm{U} / \mathrm{gHb})$ & $13.33 \mathrm{ab}$ & $\mathbf{2 7 . 6 3} \mathrm{a}$ & $24.75 \mathrm{~b}$ & $\mathrm{~b}$ & $\mathbf{2 9 . 1 0} \mathrm{a}$ & $\mathrm{b}$ & $12.62 \mathrm{~b}$ & $23.83 \mathrm{ab}$ \\
MDA & $11.4 \pm 1.96$ & $\mathbf{2 9 . 7 3} \pm \mathbf{7 . 5 3}$ & $19.29 \pm$ & $17.06 \pm 2.28$ & $20.17 \pm$ & $25.16 \pm 1.66$ & $23.49 \pm$ & $25.24 \pm$ \\
$(\mathrm{nmol} / \mathrm{gHb})$ & $\mathrm{a}$ & $\mathrm{b}$ & $0.71 \mathrm{ab}$ & $\mathrm{ab}$ & $1.01 \mathrm{ab}$ & $\mathrm{ab}$ & $3.47 \mathrm{ab}$ & $9.38 \mathrm{ab}$ \\
\hline
\end{tabular}

*Different letters in each row indicate significant difference between groups.

\section{DISCUSSION}

The results of leukogram assessment revealed that acute lead exposure induced a significant elevation in total leukocyte, lymphocyte and neutrophil counts in rats. These effects partially subsided by treatment with silymarin for 10 days or a combination of $\mathrm{d}$ penicillamine and silymarin.

Lead intoxication has been shown to stimulate a striking leukocytosis, due to neutrophilia and monocytosis, probably because of possible inflammations and immune response caused by this heavy metal in mice and rats [2021]. In addition, occupational long-term exposures to lead were demonstrated to induce an increase in total leukocyte, neutophil and monocyte counts, in association with elevated blood lead level [22-23].

On the other hand, there is evidence of antiinflammatory properties of silymarin [24], to which the beneficial impact of this herbal drug on leukocyte counts in the present study can be attributed.

In the present study, a microcytic hypochromic anemia was consistently observed in all lead exposed rats that were not affected by any of the treatments.

Heme synthesis is significantly suppressed by lead through inhibition of three major enzymes involved in this pathway, including $\delta$ aminolevulinic acid dehydratase (ALAD), aminolevulinic acid synthetase (ALAS), and ferrochelatase [25-26] while its effect on ALAD is more profound. In addition, lead is capable to induce oxidative damage to erythrocyte proteins and membrane at high concentrations which plays an important role in erythrocyte destruction. Hence, the mechanic and osmotic fragilities induced by lead in erythrocytes could be reduced by various antioxidants [5].

The extracts of the flowers and leaves of Silybum marianum have been used for centuries to treat liver disorders while it is accepted as a safe herbal product with anti-oxidant properties and no health hazard or significant side effect [27-28]. Despite a long history of its use and the large number of people who consume this substance, no conclusive data on its clinical efficacy in prevention or recovery of chemical hemotoxicity can be identified.

In the present study, none of the treatments (d-penicillamine nor silymarin) were effective in preventing or overcoming anemia in dose and duration applied in the present study. It might be due to the high level of lead exposure or the method through which d-penicillamine or silymarin were administered.

Erythrocyte osmotic fragility was not affected by any of the treatments in the current study. In other words, acute lead exposure did not alter erythrocyte resistance to hypoosmotic environments. In contrast, a decline in erythrocyte osmotic fragility was reported in workers occupationally exposed to lead with a doseresponse relationship between blood lead level and osmotic fragility [29-30]. This tendency was assumed to be related to the alterations of RBC membranes, including an increase in membrane cholesterol following lead exposure. The absence of significant changes in erythrocyte osmotic fragility in the present study could be due to the acute lead intoxication in which the destruction in erythrocyte membrane and oxidative stress most likely resulted in direct removal of the damaged erythrocytes rather than remaining in circulation and altering the osmotic fragility.

In the present experiment, lead exposure resulted in increased activity of erythrocyte SOD and Gpx enzymes. Blood levels of the antioxidant enzymes SOD and catalase (CAT) has been elevated or suppressed by lead depending mainly on the level and duration of exposure. Higher levels of exposure to $\mathrm{Pb}$ in experimental or cross- 
sectional studies are reported to cause increases in the activity of these enzymes as a consequence of elevated reactive oxygen species production [3, 31-32]. However, the activities of GPx, CAT and SOD as major antioxidant enzymes in the erythrocytes significantly crashed usually at chronic exposure with lower amounts of lead [33]. Lead has the ability to bind to the sulfhydryl group of enzymes of the antioxidative defense system, as well as replacing divalent bioelements that serve as their important co-factors, resulting in their inactivation [3, 33-34].

None of the treatments was able to adverse the lead induced SOD elevation in the current study except silymarin pretreatment, while Gpx activity was successfully reduced by silymarin administration for 10 days or a combination of $d$ penicillamine and silymarin. This reflects that silymarin can prevent the action of free radicals and oxidative stress in erythrocytes following lead intoxication. However, once the oxidative damage is produced by lead, silymarin is almost unable to reverse its consequences. Silymarin ability to act as cellular antioxidant has been attributed to its various beneficial effects including free radical scavenging, reduction of membrane lipid peroxidation and enhancement of GSH reserves [24].

MDA concentration, as a marker of lipid peroxidation, was significantly increased in the lead exposed rats. However, it was effectively alleviated in response to d-penicillamine or silymarin treatments. Similar results were reported by other researchers who observed a positive correlation between erythrocyte MDA levels and blood $\mathrm{Pb}$ levels [5, 33-35].

The MDA level was perfectly reduced by silymarin, as well as d-penicillamine in the present study, indicating a significant protection against the oxidative damage produced by lead. This finding seems to be compatible with Oda and El-Ashmawy's [36] in which silymarin returned MDA and GSH to the normal values, improved serum biochemical and histopathological changes of kidney and liver following acute mercury intoxication. Furthermore, simultaneous treatment with vitamin-E could prevent lipid peroxidation following 15 and 30 days of lead exposure in rats [5]. There is also evidence of protective effect of vitamin $\mathrm{C}$ and silymarin against toxic effects of lead on rat liver tissue in a previous study [8].

D-penicillamine in the present dose and duration of treatment was not much effective in reducing the hematologic consequences of lead intoxication. These findings are in accordance with another study where D-penicillamine administration did not play an important role in treatment of hematologic effects of lead in subchronic intoxication in rats [37]. Eventhough this experiment was only conducted on acute lead toxicity in a limited period of time; the hematologic and oxidative consequences of intoxication, as well as comparative effects of different treatments were clearly noticeable.

\section{CONCLUSION}

Acute lead exposure induced significant leukocytosis and anemia that was associated with increased activity of erythrocyte antioxidant enzymes and lipid peroxidation. Silymarin pretreatment in contrast to d-penicillamine could alleviate lead induced oxidative stress in erythrocytes more effectively. Further studies are required to determine the possible effects of silymarin in prevention or treatment of lead induced hemotoxicity in different administration methods and in combination with other medications.

\section{ACKNOWLEDGEMENTS}

This study was supported by the Research Council of Shahid Chamran University of Ahvaz. The authors declare there is no conflict of interest.

\section{REFERENCES}

1. Flora SJS, Flora G, Saxena G. Environmental occurrence, health effects and management of lead poisoning. In: Jose SC, Jose S, editors. Lead. Amsterdam: Elsevier; 2006. P. 158-228.

2. Cao Y, Skaug MA, Andersen O, Aaseth J. Chelation therapy in intoxications with mercury, lead and copper. J Trace Elem Med Biol 2015; 31: 188-92.

3. Matović V, Buha A, Đukić-Ćosić D, Bulat Z. Insight into the oxidative stress induced by lead and/or cadmium in blood, liver and kidneys. Food Chem Toxicol 2015; 78: 130-40.

4. Flora G, Gupta D, Tiwari A. Toxicity of lead: a review with recent updates. Interdiscip Toxicol 2012; 5: 47-58.

5. Rendon-Ramirez A, Cerbon-Solorzano J, Maldonado-Vega M, Quintanar-Escorza MA, Calderon-Salinas JV. Vitamin-E reduces the oxidative damage on d-aminolevulinic dehydratase induced by lead intoxication in rat erythrocytes. Toxicol in Vitro 2007; 21: 1121-6. 
6. Aaseth J, Skaug MA, Cao Y, Andersen O. Chelation in metal intoxication - principles and paradigms. J Trace Elem Med Biol 2015; 31: 2606.

7. González-Ramírez D, Zuñiga-Charles M, NarroJuárez A. Mobilization of lead in patients with chronic poisoning by that metal. Oral penicillamine. Arch Invest Med 1990; 21: 279-83.

8. Shalan MG, Mostafa MS, Hassouna MM, El-Nabi SEH, El-Refaie A. Amelioration of lead toxicity on rat liver with Vitamin $\mathrm{C}$ and silymarin supplements.Toxicol 2005; 206: 1-5.

9. Soto CP, Perez BL, Favari LP, Reyes JL. Prevention of alloxan-induced diabetes millitus in the rat by silymarin. CompBiochemPhysiol C Toxicol Pharmacol 1998; 119: 125-9.

10. Hagymasi K, Kocsis I, Lugasi A, Fesher J, Blazovics A.Extrahepatic biliary obstruction: can silymarin protect liver function? Phytother Res 2002;16:78-80.

11. Valenzuela A, Garrido A. Biochemical bases of the pharmacological action of the flavonoid silymarin and of its structural isomer silibinin. Biol Res 2002;27:105-12.

12. Kren V, Walterova D. Silybin and silymarin-new effects and applications. Biomed Pap Med Fac Univ Palacky Olomouc Czech Repub 2005; 149: 29-41.

13. Matsuda T, Ferreri K, Todorov I, Kuroda Y, Smith CV, Kandeel F, et al. Silymarin protects pancreatic $\beta$-cells against cytokine-mediated toxicity: implication of c-Jun NH2-terminal kinase and janus kinase/signal transducer and activator of transcription pathways. Endocrinology 2005;146(1):175-85.

14. Abdou HM, Hassan MA. Protective role of omega-3 polyunsaturated fatty acid against lead acetate-induced toxicity in liver and kidney of female rats. BioMed Res Int 2014; 2014: 4357-8.

15. Siatkowski RM, Yanovitch TL, Ash JD. The effects of D-penicillamine on a murine model of oxygen-induced retinopathy.J AAPOS 2011; 15: 370-3.

16. Freitag AF, Cardia GF, Da Rocha BA, Aguiar RP, Silva-Comar FM, Spironello RA, et al. Hepatoprotective effect of silymarin (Silybum marianum) on hepatotoxicity induced by acetaminophen in spontaneously hypertensive rats. J Evidence-Based Complementary Altern Med 2015; 538317-8.

17. Meyer DJ, Harvey JW. Veterinary laboratory medicine, third ed. London: Saunders; 2004.

18. Jain NC. Hematologic techniques. In: Jain NC, editor. Schalm's Veterinary Hematology, fourth ed. Philadelphia: Lea \&Febiger; 1986. P. 20-86.

19. Placer ZA, Cushman LL, Johnson BC. Estimation of product of lipid peroxidation (malondialdehyde) in biochemical systems. Anal. Biochem 1966; 16: 359-64.

20. Sharma R, Panwar K, Mogra S. Effects of prenatal and neonatal exposure to lead on white blood cells in Swiss mice. J Cell MolBiol 2012;10:33-40.

21. Nikolić R, Krstić N, Jovanović J, Kocić G, Cvetković TP, Radosavljević-Stevanović N. Monitoring the toxic effects of $\mathrm{Pb}, \mathrm{Cd}$ and $\mathrm{Cu}$ on hematological parameters of Wistar rats and potential protective role of lipoic acid and glutathione. Toxicol Ind Health 2015;31:239-46.

22. Kuo HW, Hsiao TY, Lai JS. Immunological effects of long-term lead exposure among Taiwanese workers. Arch Toxicol 2001; 75(10): 569-73.

23. Khan SY, Arshad M, Arshad N, Shafaat S, Tahir HM. A probable role of blood lead levels on some haematological parameters in traffic police, Lahore, Pakistan. Toxicol Ind Health 2016; 32: 795-800.

24. Colturato CP, Constantin RP, Maeda AS, Constantin RP, Yamamoto NS, Bracht A, et al. Metabolic effects of silibinin in the rat liver. Chem Biol Interact 2012;195:119-32.

25. Sakai T. Biomarkers of lead exposure. Ind Health 2000; 38: 127-42.

26. Wang Q, Zhao HH, Chen JW,Hao QL, Gu KD, Zhu YX, et al. $\delta$-Aminolevulinic acid dehydratase activity, urinary $\delta$-aminolevulinic acid concentration and zinc protoporphyrin level among people with low level of lead exposure. Int J Hyg Environ Health 2010; 213: 52-8.

27. Toklu HZ, Tunali Akbay T, Velioglu-Ogunc A, Ercan F, Gedik N, Keyer-Uysal M, et al. Silymarin, the antioxidant component of Silybum marianum, prevents sepsis-induced acute lung and brain injury. J Surg Res 2008; 145: 214-22.

28. Shaker E, Mahmoud H, Mnaa S. Silymarin, the antioxidant component and Silybum marianum extracts prevent liver damage. Food Chem Toxicol 2010; 48: 803-6.

29. Karai I, Fukumoto K, Horiguchi S. The effect of lead on intracellular water content of human red blood cells 1 An experiment in vitro (in Japanese). Jpn J Ind Health 1891; 23: 305-7.

30. Karai I, Fukumoto K, Horiguchi SI. Relationships between osmotic fragility of red blood cells and various hematologic data in workers exposed to lead. Int Arch Occup Environ Health 1982;50: 1724.

31. Tandon SK, Singh S, Prasad S, Srivastava S, Siddiqui MK. Reversal of lead-induced oxidative stress by chelating agent, antioxidant, or their combination in the rat. Environ Res 2002; 90: 616.

32. Ahamed M, Verma S, Kumar A, Siddiqui MK. Environmental exposure to lead and its correlation 
with biochemical indices in children. Sci Total Environ 2005; 346: 48-55.

33. Omobowale TO, Oyagbemi AA, Akinrinde AS, Saba AB, Daramola OT, Ogunpolu BS, et al. Failure of recovery from lead induced hepatoxicity and disruption of erythrocyte antioxidant defence system in Wistar rats. Environ Toxicol Pharmacol 2014; 37: 1202-11.

34. Hsu PC, Guo YL. Antioxidant nutrients and lead toxicity. Toxicol 2002; 180: 33-44.

35. Kasperczyk S, Dobrakowski M, Kasperczyk A, Machnik G, Birkner E. Effect of N-acetylcysteine administration on the expression and activities of antioxidant enzymes and the malondialdehyde level in the blood of lead-exposed workers. Environ Toxicol Pharmacol 2014; 37: 638-47.

36. Oda SS, El-Ashmawy IM. Protective effect of silymarin on mercury-induced acute nephrohepatotoxicity in rats. Glob Vet 2012; 9:376-83.

37. Golalipour MJ, Roshandel D, Roshandel G, Ghafari S, Kalavi M, Kalavi K. Effect of lead intoxication and D-penicillamine treatment on hematological indices in rats. Int J Morphol 2007; 25: 717-22. 